\title{
PERSEPSI MAHASISWA TERHADAP MUTU INTERNAL FAKULTAS EKONOMI UNIVERSITAS LANCANG KUNING
}

\author{
Oleh \\ Prama Widayat \\ Universitas Lancang Kuning-Pekanbaru \\ pramawidayat@unilak.ac.id
}

diterima 08 Januari 2020, direvisi 20 Pebruari 2020, diterbitkan 29 Pebruari 2020

\begin{abstract}
The Faculty of Economics, Lancang Kuning University has Management and Accounting study programs with more than 2000 students. Of course they have felt the atmosphere of lectures for several semesters with all the advantages and disadvantages possessed by the Faculty of Economics, Lancang University. For this reason, further research needs to be done to get responses from students about the internal quality of the yellow faculty of economics. because they are users of the college. It is hoped that this research will provide positive input for the faculty of Economics at Lancang Kuning University to improve all the deficiencies that exist, then maintain or can improve the existing advantages.
\end{abstract}

\section{Keywords: Quality, Student, Perception}

\begin{abstract}
Abstrak
Fakultas Ekonomi, Universitas Lancang Kuning memiliki program studi Manajemen dan Akuntansi dengan lebih dari 2000 mahasiswa. Tentu saja mereka telah merasakan suasana perkuliahan selama beberapa semester dengan segala kelebihan dan kekurangan yang dimiliki oleh Fakultas Ekonomi, Universitas Lancang. Untuk alasan ini, penelitian lebih lanjut perlu dilakukan untuk mendapatkan tanggapan dari mahasiswa tentang kualitas internal fakultas ekonomi kuning. karena mereka adalah pengguna kampus. Diharapkan penelitian ini akan memberikan masukan positif bagi fakultas Ekonomi di Universitas Lancang Kuning untuk meningkatkan semua kekurangan yang ada, kemudian mempertahankan atau dapat meningkatkan keunggulan yang ada.
\end{abstract}

\section{Kata kunci: Kualitas, Mahasiswa, Persepsi}

\section{PENDAHULUAN}

Perkembangan jumlah mahasiswa yang masuk ke Fakultas Ekonomi Universitas Lancang Kuning setiap tahunnya tidak terlalu jauh berbeda yang berada pada kisaran 400 hingga 500 mahasiswa, untuk tahun ajaran 2018-2019 saja jumlah mahasiswa baru Fakultas ekonomi hampir 500 orang, untuk tahun ajaran 2019-2020 juga hampir 500 mahasiswa yang masuk. 
Jika dilihat keseluruhan jumlah mahasiswa aktif Fakultas Ekonomi Universitas Lancang Kuning (Unilak) sejak tahun 2015 hingga 2019 lebih kurang sebanyak 2000 Mahasiswa.

Tabel 1 Mahasiswa Fakultas Ekonomi

\begin{tabular}{|c|c|c|c|}
\hline $\begin{array}{l}\text { Tahun } \\
\text { ajaran }\end{array}$ & $\begin{array}{c}\text { Program } \\
\text { studi }\end{array}$ & Jumlah & Total \\
\hline \multirow{2}{*}{$2017-2018$} & Manajemen & 319 & \multirow{2}{*}{484} \\
\hline & Akuntansi & 165 & \\
\hline \multirow{2}{*}{ 2018-2019 } & Manajemen & 304 & \multirow{2}{*}{503} \\
\hline & Akuntansi & 199 & \\
\hline \multirow{2}{*}{ 2019-2020 } & Manajemen & 311 & \multirow{2}{*}{473} \\
\hline & Akuntansi & 162 & \\
\hline
\end{tabular}

Dengan jumlah sekitar 2000 mahasiswa membuat Fakultas Ekonomi Unilak menjadi Fakultas dengan jumlah mahasiswa terbanyak diantara fakultas lainnya yang di Unilak. Mahasiswa yang sudah beberapa semester mengikuti perkuliahan di Fakultas Ekonomi Unilak tentunya sudah merasakan bagaimana proses perkuliahan yang dijalani, bagaimana kualitas dosen-dosen yang mengajarkan mereka, bagaimana fasilitas yang ada, bagaimana ketersedian buku-buku diperpustakaan, bagaimana pelayanan tata usaha yang mereka terima.

Proses perkuliahan yang berlangsung apakah sesuai dengan waktu yang telah ditetapkan, dimana masuk kuliah dimulai jam 8.00 WIB untuk sesi pertama, jam 10.30 WIB untuk sesi kedua dan jam 13.30 WIB untuk sesi ketiga. Biasanya toleransi keterlambatan adalah 15 menit dari waktu masuk yang telah ditetapkan, apakah masih ada perkuliahan yang dilakukan diluar jam tersebut.

Kemudian untuk kualitas dosen-dosen yang mengajarkan mahasiswa apakah materi yang diberikan sesuai dengan RPS, apakah materi tersebut di update atau bahkan materi tersebut sudah tidak relevan lagi karena dipakai sejak 10 tahun yang lalu, padahal perlu di update setiap tahun, dua tahun atau tiga tahun sekali karena perkembangan bidang ekonomi akan selalu update sehingga mahasiswa tidak ketinggalan wawasan. Kemudian apakah dosen yang mengajar sudah sesuai dengan kompetensi, apakah dosen tersebut menguasai apa yang diajarkan kepada mahasiswa, tentunya hal ini untuk memberikan ilmu yang tepat kepada mahasiswa.

Dari segi fasilitas apakah mahasiswa sudah mendapatkan fasilitas perkuliahan yang memadai dari uang kuliah yang sudah mereka bayarkan seperti apakah kursi yang mereka gunakan layak pakai, apakah pendingan ruangan tersedia dan bisa digunakan, apakah lampu ruangan perkuliahan menyala dengan terang agar mendukung perkuliahan dimalam hari, bagaimana kebersihan ruangan kelas untuk belajar.

Kemudian ketersedian bahan bacaan diperpustakaan, apakah buku yang dicari oleh mahasiswa tersedia dikampus untuk keperluan penulisan skripsi, membuat makalah tugas dari dosen, ataupun hanya sekedar ingin membaca buku yang ada. apakah buku yang ada diperpustakaan update atau bahkan kebanyakan buku-buku lama sedangkan buku-buku baru belum terlalu banyak, serta kenyamanan ruangan perpustakaan karena kenyamanan sangat diperlukan bagi mereka yang sedang membaca ataupun membuat tugas.

Pelayanan tata usaha yang diterima oleh mahasiswa apakah sudah sesuai harapan atau malahan tidak sesuai dengan ekspektasi mahasiswa, seperti keramahan petugas tata usaha, kecepatan dalam pelayanan, hadir tepat waktu dan memberikan informasi yang dibutuhkan oleh para mahasiswa.

Transparansi tentang beasiswa yang ada, apakah mahasiswa diberitahukan setiap ada informasi beasiswa karena kita ketahui tidak semua mahasiswa yang berasal dari keluarga yang mampu, banyak diantara mereka yang berasal dari keluarga yang tidak mampu sehingga mereka berharap mendapatkan informasi beasiswa dari fakultas. Walaupun mereka belum tentu diterima untuk pengajuan beasiswa tersebut tetapi setidaknya mereka sudah mengetahui apa saja beasiswa yang ada dan apa saja syarat yang harus mereka lengkapi untuk setiap pengajuan beasiswa 
Untuk itulah perlu dilakukan penelitian lebih lanjut untuk mengetahui keunggulan dan kelemahan yang ada di Fakultas Ekonomi Universitas Lancang Kuning dai Sudut pandang mahasiswa.

\section{METODE}

Metode pengambilan sampel yang digunakan adalah stratified random sampling yaitu data sebelumnya dikelompokkan kedalam tingkatan tertentu seperti dimulai dari tingkatan yang lebih tinggi, sedang dan rendah dimana dalam penelitian ini dimulai dari mahasiswa semester 7 , semester 5, semester 3 dan semester 1 .

\section{HASIL DAN PEMBAHASAN}

\section{Proses perkuliahan}

Tabel 1. Proses Perkuliahan

\begin{tabular}{|l|c|c|c|}
\hline \multicolumn{1}{|c|}{ Item } & Cukup & Sedang & Baik \\
\hline $\begin{array}{l}\text { Dosen datang tepat } \\
\text { waktu }\end{array}$ & $30 \%$ & $50 \%$ & $20 \%$ \\
\hline $\begin{array}{l}\text { Dosen menguasai } \\
\text { materi }\end{array}$ & $10 \%$ & $40 \%$ & $50 \%$ \\
\hline $\begin{array}{l}\text { Mahasiswa mudah } \\
\text { memahami }\end{array}$ & $20 \%$ & $40 \%$ & $40 \%$ \\
\hline
\end{tabular}

Berdasarkan tabel 1 diatas bahwa terlihat penilaian mahasiswa tentang dosen yang datang tepat waktu hanya $20 \%$, sebanyak $50 \%$ kadang datang tepat waktu dan kadang terlambat, termasuk $30 \%$ mengatakan sering terlambat dan bahkan terlambat terus dari waktu perkuliahan yang telah ditetapkan.

Untuk penguasaan meteri kuliah ratarata mahasiswa menjawab sebanyak $50 \%$ dosen sudah mengusai materinya sehingga mereka mampu menangkap apa yang disampaikan, sedangkan $10 \%$ menjawab masih ada dosen yang kurang menguasai materi yang diberikan kepada mahasiswa.

\section{Fasilitas kuliah}

Tabel 2 Fasilitas Kuliah

\begin{tabular}{|l|c|c|c|}
\hline \multicolumn{1}{|c|}{ Item } & Cukup & Sedang & Baik \\
\hline Ketersediaan Kursi & $10 \%$ & $10 \%$ & $80 \%$ \\
\hline Kursi layak digunakan & $10 \%$ & $10 \%$ & $80 \%$ \\
\hline $\begin{array}{l}\text { Lampu penerangan di } \\
\text { kelas }\end{array}$ & $50 \%$ & $15 \%$ & $35 \%$ \\
\hline
\end{tabular}

Pada tabel 2 diatas dapat dilihat sebagian besar responden mengatakan bahwa ketersedian kursi diruangan kuliah dalam keadaan baik sebanyak $80 \%$ tetapi masih ada kursi yang kurang layak digunakan sebanyak $10 \%$. Untuk lampu penerangan kelas untuk dimalam hari masih dianggap kurang karena terbukti penilaian mahasiswa $50 \%$ mengatakan lampunya kurang terang dan tidak menyala semuanya.

\section{Buku perpustakaan}

Tabel 3 Buku Perpustakaan

\begin{tabular}{|l|c|c|c|}
\hline \multicolumn{1}{|c|}{ Item } & Cukup & Sedang & Baik \\
\hline Ketersediaan Buku & $30 \%$ & $10 \%$ & $60 \%$ \\
\hline Buku up date & $35 \%$ & $15 \%$ & $50 \%$ \\
\hline
\end{tabular}

Dilihat dari tabel 3 diatas terlihat bahwa ketersediaan buku $60 \%$ menyatakan sudah baik dan $30 \%$ menyatakan masih ada buku-buku yang belum tersedia. Untuk kebaruan atau up-date buku yang tersedia masih perlu diperbaharui karena sebanyak $50 \%$ responden yang menyatakan up-date sedangkan $35 \%$ masih menyatakan kurang up-date.

\section{Pelayanan tata usaha}

Tabel 4 Pelayanan Tata Usaha Fekon Unilak

\begin{tabular}{|l|c|c|c|}
\hline \multicolumn{1}{|c|}{ Item } & Cukup & Sedang & Baik \\
\hline Datang tepat waktu & $5 \%$ & $15 \%$ & $85 \%$ \\
\hline Keramahan & $10 \%$ & $10 \%$ & $80 \%$ \\
\hline $\begin{array}{l}\text { Kemudahan } \\
\text { memperoleh informasi }\end{array}$ & $5 \%$ & $5 \%$ & $90 \%$ \\
\hline
\end{tabular}

Dari tabel 4 diatas dapat dilihat bahwa karyawan tata usaha sudh datang tepat pada waktu sebanyak $85 \%$ sedangkan $5 \%$ menyatakan belum datang sesuai waktunya. Untuk keramahan karyawan tata usaha maka penilaian responden memberikan angka $80 \%$ dengan kategori baik, sedangkan $10 \%$ masih menyatakan cukup (kurang ramah). Dalam hal kemudahan memperoleh informasi mahasiswa menyatakan bahwa baik sebanyak 90\% sedangkan 5\% menyatakan cukup (masih kurang lengkap) 


\section{Informasi beasiswa}

Tabel 5 Informasi Beasiswa

\begin{tabular}{|l|c|c|c|}
\hline \multicolumn{1}{|c|}{ Item } & Cukup & Sedang & Baik \\
\hline $\begin{array}{l}\text { Transparansi informasi } \\
\text { beasiswa }\end{array}$ & $45 \%$ & $30 \%$ & $25 \%$ \\
\hline $\begin{array}{l}\text { Kemudahan info } \\
\text { mendapatkan beasiswa }\end{array}$ & $40 \%$ & $35 \%$ & $25 \%$ \\
\hline Pro aktif pihak fakultas & $40 \%$ & $30 \%$ & $30 \%$ \\
\hline
\end{tabular}

Pada tabel 5 diatas terlihat bahwa transparansi informasi beasiswa di fakulta ekonomi masih tergolong kurang transparan karena $45 \%$ menyatakan cukup dan hanya $25 \%$ menyatakan baik. Kemudahan dalam mendapatkan informasi beasiswa juga $40 \%$ menyatakan cukup, termasuk sikap pro afktif pihak fakultas dalam memberikan informasi beasiswa yang mendapatkan penilaian $40 \%$ kategori cukup. Secara keseluruhan informasi beasiswa masih mendapatkan nilai rendah dari mahasiswa.

\section{Kelembagaan mahasiswa}

Tabel 6 Kegiatan Kemahasiswaan

\begin{tabular}{|l|c|c|c|}
\hline \multicolumn{1}{|c|}{ Item } & Cukup & Sedang & Baik \\
\hline $\begin{array}{l}\text { Transparansi anggaran } \\
\text { kemahasiswaan }\end{array}$ & $35 \%$ & $50 \%$ & $15 \%$ \\
\hline $\begin{array}{l}\text { Nilai manfaat kegiatan } \\
\text { kemahasiswaan }\end{array}$ & $20 \%$ & $40 \%$ & $40 \%$ \\
\hline $\begin{array}{l}\text { Prestasi yang bisa } \\
\text { dibanggakan }\end{array}$ & $30 \%$ & $40 \%$ & $30 \%$ \\
\hline
\end{tabular}

Dari tabel 6 dapat dilihat sebanyak $35 \%$ responden menyatakan bahwa belum adanya transparan anggaran kemahasiswaan, sedangkan yang menyatakan baik hanya $15 \%$ saja. Untuk nilai manfaat kegiatan kemahasiswaan sebanyak $40 \%$ menyatakan baik dan yang menyatakan kurang masih $20 \%$ responden. Kemudian apakah prestasi lembaga kemahasiswaan itu bisa dibanggakan maka jawaban responden sebanyak $30 \%$ menyatakan baik dan cukup sebanyak 30\%. Artinya dalam bidang kemahasiswaan masih mendapatkan penilaian rendah dari mahasiswa.

Setelah dilakukan pengumpulan sampel terhadap 120 mahasiswa Fakultas Ekonomi Universitas Lancang Kuning dengan metode stratified random sampling dimana setiap angkatan diambil 30 mahasiswa dimulai angkatan tahun 2016,
2017, 2018 dan 2019 dari program studi Manajemen dan Akuntansi

Dimana mahasiswa diminta memberikan persepsinya tentang mutu internal fakultas Ekonomi Universitas Lancang Kuning yang dilihat dari beberapa aspek, berikut penjelesannya :

\section{Proses perkuliahan}

Mahasiswa memberikan pandangan bahwa masih ada dosen yang datang tidak sesuai dengan jadwal yaitu sebanyak 30\% mahasiswa menyatakan masih ada dosen yang datang terlambat, sebanyak $20 \%$ menyatakan dosen sudah ontime sesuai waktu kuliah jam 08:00, 10:30 dan 13:30. Sedangkan $50 \%$ menyatakan kadang terlambat dan kadang ontime. Padahal kedisiplinan merupakan kunci kesuksesan dalam bekerja sebagaimana juga disampaikan oleh Mangkunegara (2015:1249-1250) bahwa seorang karyawan yang memiliki disiplin kerja maka mereka cenderung memilik prestasi kerja yang baik. Maka dari itu perlu ditanamkan kedisiplinan dimulai dari dosen sehingga mahasiswa juga akan otomatis mengikuti karena dosen yang disiplin akan memberikan motivasi kepada mahasiswa untuk lebih menghargai waktu.

Selanjutnya mahasiswa juga memberikan tanggapan, dalam proses perkuliahan (Braxton, 2000:575-590) mereka juga membutuhkan materi yang up-date sehingga sesuai dengan perkembangan zaman, kualitas buku-buku yang digunakan oleh dosen dalam perkuliahan sangat membantu mahasiswa dalam menyerap ilmuilmu dan wawasan yang terbaru (Andreu, 2006:73-82) dan ini juga didukung oleh Lomas (2005:73-82) bahwa seorang pengajar juga harus memiliki kinerja yang baik dalam penyampaian materi, serta dosen yang berkualitas akan menghasilkan mahasiswa yang berkualitas (Gibbs, 2014:159-165).

\section{Fasilitas kuliah}

Kebutuhan yang tak kalah penting adalah kelengkapan fasilitas perkuliahan terutama dalam hal kursi kuliah, white board, proyektor dan lampu penerangan ruangan. 
Kelengkapan fasilitas perkuliahan juga menjadi perhatian penting dalam membangun mutu perkuliahan (Ndirangu, 2011:208-223) dan (Lamancusa, 2008:5-11)

Penilaian untuk kondisi fasilitas yang dimiliki Fakultas Ekonomi Universitas Lancang Kuning 80\% sudah baik tinggal $20 \%$ lagi perlu perbaikan dan peningkatan seperti penambahan kursi kuliah dan juga penambahan penerangan untuk perkuliahan malam hari. Dalam menunjang proses belajar mengajar, fasilitas kuliah juga sangat menentukan kualitas pembelajaran (Ginns, 2007:53-64) karena bagaimanapun juga bahwa interaksi yang terjadi dalam ruangan akan berjalan dengan baik jika didukung oleh fasilitas yang lengkap (Gogoulou, 2007:242256).

Ketika dosen menyampaikan materi perkuliahan menggunakan proyektor maka itu akan lebih menarik jika hanya sekedar berbicara didepan kelas, karena mahasiswa akan lebih mudah menangkap dalam bentuk visualisasi dan juga gambar. Termasuk jika ditambah dengan menggunakan pembelajaran berbasis multimedia (Mulia, 2019:144-152) Apa jadinya jika proyektor yang ada diruangan kelas tidak bisa digunakan dan juga lampu penerangan kelas tidak terang maka akan menganggu kenyamanan mahasiswa dalam proses pembelajaran.

Mahasiswa sudah membayar uang kuliah tentunya juga ditunjang dengan kompensasi fasilitas yang memadai (Widayat, 2018:67-75) karena dalam persaingan bisnis pendidikan setiap kampus berlomba menawarkan segala fasilitas yang mereka miliki, karena itu harus pandai mengelola keuangan demi menunjang operasional (Widayat, 2018:8).

\section{Buku perpustakaan}

Selain itu yang tidak boleh dilupakan adalah ketersediaan buku bacaan atau buku referensi disebuah perguruan tinggi, dalam persepsi mahasiswa bahwa mereka menginginkan perpustakaan yang di Fakultas Ekonomi Universitas Lancang Kuning lebih banyak lagi menyediakan buku-buku bacaan dalam bidang perpajakan dan manajemen lainnya, saat ini buku yang tersedia sudah $60 \%$ memenuhi kebutuhan mahasiswa, kekurangan buku $40 \%$ lagi mereka harus mencari kekampus lain seperti Universitas Riau dan juga ke perpustakaan wilayah.

Buku adalah jendela ilmu, dengan membaca mahasiswa akan semakin kaya wawasan dan juga ilmu pengetahuan, bagaimana lulusan itu akan berkualitas sementara bahan bacaan mereka tidak tersedia. Dibeberapa negara bahkan beberapa lembaga membangun perpustakaan umum bagi masyarakat (Eve, 2007:393-406).

Ketersediaan buku diperpustakaan juga tidak terlepas dari peran pustakawan (Maitaouthong, 2012:52-62) karena mereka yang akan memberikan pemahaman kepada mahasiswa dan juga dosen (Booth, 2003: 225-231) untuk buku-buku baru yang relevan. Setiap waktu ilmu berkembang (Wai Fan, 2005:43-50) dan perlu update setiap tahunnya.

\section{Pelayanan tata usaha}

Karyawan tata usaha sudah datang tepat pada waktu sebanyak $85 \%$, kemudian sebanyak $10 \%$ menyatakan cukup yaitu kadang datang tepat waktu dan kadang terlambat, dan 5\% menyatakan belum datang sesuai waktunya karena dianggap terlambat. Bagi mahasiswa, karyawan pelayanan tata usaha wajib datang sebelum waktunya sehingga saat jam kerja dimulai jam 8 pagi maka mahasiswa tidak perlu menunggu lama, sesuai dengan penelitian Thaief (2015:23-15) dan Mangkunegara (2015: 318328) bahwa kedisiplinan dalam bekerja wajib dimiliki oleh setiap karyawan terutama bagian pelayanan. Selain itu kesiplinan juga mendorong terjadinya peningkatan produktitas kerja (Elqadri, 2015:59-65).

Untuk keramahan karyawan tata usaha maka penilaian responden memberikan angka $80 \%$ dengan kategori baik, $10 \%$ menyatakan sedang dan $10 \%$ masih menyatakan cukup (kurang ramah). Sesuai dengan penelitian Dai (2015:42-55), Xu (2015:105-116) dan Radojevic (2015:13-21) bahwa pelayanan yang ramah akan 
memberikan kepuasaan kepada customer, dimana difakultas ekonomi Unilak yang menjadi customer adalah para mahasiswa.

Dalam hal kemudahan memperoleh informasi mahasiswa menyatakan bahwa sebanyak $90 \%$ menyatakan baik sedangkan $10 \%$ menyatakan cukup (masih kurang lengkap). Artinya pelayanan tata usaha mendapatkan nilai baik dari mahasiswa dan ini perlu dipertahankan dan ditingkatkan terus, karena kenyamanan mahasiswa merupakan nilai plus yang bisa diberikan. Karena dasarnya yang namanya pelayanan adalah kemudahan dalam mendapatkan informasi sesuai dengan hasil penelitian Escoffery (2005:183-188) dan Metzger (2003:271-290).

\section{Informasi beasiswa}

Transparansi informasi beasiswa di Fakultas Ekonomi masih tergolong kurang transparan karena $45 \%$ menyatakan cukup dan hanya 25\% menyatakan baik. Mahasiswa menganggap tidak adanya transparansi dalam informasi beasiswa sehingga mereka kurang mengetahui dan kadang-kadang informasinya satu hari sebelum deadline sehingga mana mungkin mereka mempersiapkan syaratnya. Sebagaimana yang dikemukan oleh Bensimon (2007:441469) bahwa beasiswa tersebut akan menjadi motivasi bagi seorang mahasiswa, karena dengan itu mereka bisa melanjutkan kuliah dan tidak jarang mahasiswa sebelum masuk perguruan tinggi maka yang pertama dilihat adalah beasiswa yang tersedia (Hafler, 2006:411-425)

Sejalan dengan itu bahwa kemudahan dalam mendapatkan informasi beasiswa juga mendapatkan respon $40 \%$ menyatakan cukup, termasuk sikap pro afktif pihak fakultas dalam memberikan informasi beasiswa mendapatkan penilaian. Secara keseluruhan informasi beasiswa masih mendapatkan nilai rendah dari mahasiswa, hal ini perlu menjadi perhatian pihak fakultas karena ini juga hak dari mahasiswa, perlu pengelolaan yang lebih baik kedepannya terutama dalam keterbukaan informasi, azas keterbukaan merupakan poin penting bagi sebuah informasi (Cayanus, 2009:105-113) karena tidak jarang beasiswa menjadi indikator penting yang dicari seorang mahasiswa (Cayanus, 2008:20-26)

\section{Kelembagaan mahasiswa}

Sebanyak 35\% responden menyatakan bahwa belum adanya transparan anggaran kemahasiswaan, mereka tidak mengetahui berapa banyak anggaran kegiatan kemahasiswaan yang disediakan oleh fakultas dalam satu tahun sehingga nantinya mereka bisa menyusun rencana kerja untuk satu tahun berdasarkan anggaran yang disediakan karena mereka membayar uang kuliah setiap semester, dimana setiap uang kuliah tersebut dipotong untuk kegiatan kemahasiswaan, era sekarang menuntut keterbukaan dalam tata kelola sebuah organisasi dalam bidang keuangan (Truman, 2007:1-9) termasuk juga sebuah organisasi publik (Sol, 2013:90-107) dan hal yang sama juga didukung oleh Fard (2007:331-344)

Untuk nilai manfaat dari sebuah kegiatan kemahasiswaan sebanyak $40 \%$ menyatakan baik (bermanfaat) dan yang menyatakan kurang bermanfaat sebanyak $20 \%$ responden sedangkan sisanya menyatakan tidak tau atau tidak mau tau dengan kegiatan kemahasiswaan. Hal ini tidak terlepas dari kurang bermanfaatnya kegiatan yang dilaksanakan seperti KKBSM sementara uang yang dikeluarkan cukup besar, penggunaan uangnya juga tidak transparan sehingga rawan di korupsi.

Kemudian apakah prestasi lembaga kemahasiswaan itu bisa dibanggakan maka jawaban responden sebanyak 30\% menyatakan baik (bisa dibanggakan) dan yang menyatakan kurang membanggakan sebanyak $30 \%$ dan sisanya tidak tau sama sekali Artinya dalam bidang kemahasiswaan masih mendapatkan penilaian rendah dari mahasiswa karena minimnya prestasi yang ditunjukkan oleh lembaga kemahasiswaan tersebut.

Hal ini tidak terlepas dari peran bidang kemahasiswaan pada tingkatan fakutas dalam memberikan pembinaan dan pendampingan, bukan berarti melakukan intervensi. Jika 
mereka dilepas total maka akan terjadi kebablasan sehingga kegiatan yang dilaksanakan bersifat rutinitas tahunan dan tidak ada gebrakan, padahal generasi muda itu harus memililiki inovasi dan kreatifias (Young, 2009:74; de Souza Fleith, 2000:148153)

\section{SIMPULAN}

Secara keseluruhan hasil dari persepsi mahasiswa Fakultas Ekonomi Universitas Lancang Kuning terhadap kualitas internal Fakultas Ekonomi mendapatkan nilai baik dengan beberapa catatan bahwa mereka menginginkan adanya kedisiplinan dalam proses perkuliahan karena ini bisa menjadi sarana latihan mahasiswa, memang mahasiswa juga harus mandiri memulai kedisiplinan diri tetapi yang namanya contoh harus dimulai dari dosen yang mengajar.

Termasuk keterbukaan informasi beasiswa perlu ditingkatkan serta memanage kegiatan kemahasiswa yang mengarah pada peningkatan kapasitas mahasiswa sehingga lebih mampu bersaing tingkat nasional seperti pekan ilmiah mahasiswa nasional (PIMNAS).

Keunggulan yang mendapatkan nilai plus dari persepsi mahasiswa adalah pelayanan tata usaha yang membuat mereka nyaman dan juga ketersediaan buku yang cukup representatif diperpustakaan, agar kedepan jumlah buku perlu ditambah sesuai perkembangan setiap tahunnya.

\section{DAFTAR PUSTAKA}

Andreu, R., Canos, L., De Juana, S., Manresa, E., Rienda, L., \& Tarí, J. J. Quality performance assessment as a source of motivation for lecturers: A teaching network experience. International Journal of Educational Management, 20(1), 73-82. 2006

Bensimon, E. M. The underestimated significance of practitioner knowledge in the scholarship on student success. The Review of Higher Education, 30(4), 441-469. 2007

Booth, A., Sutton, A., \& Falzon, L. Working together: supporting projects through action learning. Health Information \& Libraries Journal, 20(4), 225-231. 2003

Braxton, J. M., Milem, J. F., \& Sullivan, A. $\mathrm{S}$. The influence of active learning on the college student departure process: Toward a revision of Tinto's theory. The Journal of Higher Education, 71(5), 569-590. 2000.

Cayanus, J. L., Martin, M. M., \& Myers, S. A. The relationship between perceived instructor self-disclosure and college student information seeking. Texas Speech Communication Journal, 33(1), 20-26. 2008.

Cayanus, J. L., Martin, M. M., \& Goodboy, A. K. The relation between teacher self-disclosure and student motives to communicate. Communication Research Reports, 26(2), 105-113. 2009.

Dai, W. D., Mao, Z. E., Zhao, X. R., \& Mattila, A. S. How does social capital influence the hospitality firm's financial performance? The moderating role of entrepreneurial activities. International Journal of Hospitality Management, 51, 42-55. 2015.

de Souza Fleith, D. Teacher and student perceptions of creativity in the classroom environment. Roeper Review, 22(3), 148-153. 2000.

Elqadri, Z. M., \& Wardoyo, D. T. W. The Influence of Motivation and Discipline Work against Employee Work Productivity Tona'an Markets. Review of European Studies, 7(12), 59. 2015.

Escoffery, C., Miner, K. R., Adame, D. D., Butler, S., McCormick, L., \& Mendell, E. Internet use for health information among college students. Journal of American College Health, 53(4), 183188. $(2005$.

Eve, J., de Groot, M., \& Schmidt, A. M. Supporting lifelong learning in public libraries across Europe. Library Review, 56(5), 393-406. 2007.

Fard, H. D., \& Rostamy, A. A. A. Promoting public trust in public organizations: Explaining the role of public 
accountability. Public Organization Review, 7(4), 331-344. 2007.

Gogoulou, A., Gouli, E., Grigoriadou, M., Samarakou, M., \& Chinou, D. A webbased educational setting supporting individualized learning, collaborative learning and assessment. Journal of Educational Technology \& Society, 10(4), 242-256. 2007.

Ginns, P., \& Ellis, R. Quality in blended learning: Exploring the relationships between on-line and face-to-face teaching and learning. The Internet and Higher Education, 10(1), 53-64. 2007.

Gibbs, G., \& Jenkins, A. Teaching large classes in higher education: How to maintain quality with reduced resources. Routledge. 2014.

Hafler, J. P., Blanco, M. A., Fincher, R. M., Lovejoy, F. H., \& Morzinski, J. Educational scholarship. Guidebook for Clerkship Directors, 3rd edn. Omaha, NE, USA: Alliance for Clinical Education. 2006.

Lomas, L., \& Nicholls, G. Enhancing teaching quality through peer review of teaching. Quality In higher education, 11(2), 137-149. 2005.

Lamancusa, J. S., Zayas, J. L., Soyster, A. L., Morell, L., \& Jorgensen, J. 2006 Bernard M. Gordon Prize Lecture*: The Learning Factory: IndustryPartnered Active Learning. Journal of engineering education, 97(1), 5-11. 2008.

Maitaouthong, T., Tuamsuk, K., \& Tachamanee, Y. The roles of university libraries in supporting the integration of information literacy in the course instruction. Malaysian Journal of Library \& Information Science, 17(1). 2012.

Mangkunegara, A. P., \& Waris, A. Effect of training, competence and discipline on employee performance in company (case study in PT. Asuransi Bangun Askrida). Procedia-Social and Behavioral Sciences, 211, 1240-1251. 2015.
Mangkunegara, A. P., \& Octorend, T. R. Effect of work discipline, work motivation and job satisfaction on employee organizational commitment in the company (Case study in PT. Dada Indonesia). Universal Journal of Management, 3(8), 318-328. 2015.

Metzger, M. J., Flanagin, A. J., \& Zwarun, L. College student Web use, perceptions of information credibility, and verification behavior. Computers \& Education, 41(3), 271-290. 2003.

Mulia, Harpa Reski. Pembelajaran berbasis multimedia : upaya memahami keberagaman gaya belajar anak. Jurnal Penjaminan Mutu. Volume 5 Nomor 2 Agustus pp. 144-154. 2019

Ndirangu, M., \& Udoto, M. O. Quality of learning facilities and learning environment: Challenges for teaching and learning in Kenya's public universities. Quality Assurance in Education, 19(3), 208-223. 2011.

Radojevic, T., Stanisic, N., \& Stanic, N. Ensuring positive feedback: Factors that influence customer satisfaction in the contemporary hospitality industry. Tourism Management, 51, 13-21. 2015.

Sol, D. A. D. The institutional, economic and social determinants of local government transparency. Journal of Economic Policy Reform, 16(1), 90107. 2013.

Thaief, I., \& Baharuddin, A. Effect of training, compensation and work discipline against employee job performance. Rev. Eur. Stud., 7, 23. 2015.

Truman, E. M. Sovereign wealth funds: the need for greater transparency and accountability (No. PB07-6). Washington, DC: Peterson Institute for International Economics. 2007.

Wai Fan, K. The role of university libraries in supporting research in Hong Kong: facing a new challenge. Campus-Wide Information Systems, 22(1), 43-50. 2005. 
$\mathrm{Xu}, \mathrm{X} ., \quad \&$ Gursoy, D. Influence of sustainable hospitality supply chain management on customers' attitudes and behaviors. International Journal of Hospitality Management, 49, 105-116. 2015.

Widayat, Prama. Manajemen Risiko dan Asuransi dalam Praktek edisi revisi. Hanum Publisher. Jawa Tengah. 2018
Widayat, Prama. Between cost chep prices and increasing high quality educational university in pekanbaru city. Jurnal Penjaminan Mutu. Volume 4 Nomor 1 Februari pp. 67-75. 2018

Young, L. P. Imagine creating rubrics that develop creativity. English Journal, 99(2), 74. 2009 